\title{
Analisis Kesulitan Belajar Matematika Siswa SMP pada Materi Aljabar Ditinjau dari Mathematics Anxiety
}

\author{
Arini Setyawati ${ }^{1}$, Novisita Ratu ${ }^{2}$ \\ ${ }^{1,2}$ Program Studi Pendidikan Matematika, Fakultas Keguruan dan Ilmu Pendidikan, Universitas Kristen Satya Wacana, \\ Jl. Diponegoro No 52-60, Salatiga, Kec. Sidorejo, Kota Salatiga, Jawa Tengah 50771 \\ 202017010@student.uksw.edu
}

\begin{abstract}
This research aims to analyze the mathematics learning difficulties experienced by junior high school students in algebra in terms of mathematics anxiety. This type of research is qualitative. The subjects of this research were 3 of 32 grade VII students of SMP N 1 Pabelan. The sampling technique used is purposive sampling. Subject selection is done by distributing anxiety questionnaires to students. The research instrument used was a algebra material test sheets and interview guidelines. Indicators of learning difficulties in this research include difficulty in transferring knowledge, difficulty in counting, difficulty in visual perception, and lack of understanding of mathematical language. The results of this research indicate that each student with different levels of mathematics anxiety, namely high, medium, and low anxiety levels, has different learning difficulties. Students with high levels of math anxiety experience difficulty in each indicator of difficulty. Students with mathematics anxiety level are having difficulty in transferring knowledge, difficulty in counting, and lack of understanding of mathematical language. Meanwhile, students with low levels of mathematics anxiety only experienced one learning difficulty in algebraic material, namely the difficulty in transferring knowledge.
\end{abstract}

Keywords: Mathematics Learning Difficulty, Mathematics Anxiety, Algebra

\begin{abstract}
Abstrak
Penelitian ini dilakukan dengan tujuan untuk menganalisis kesulitan belajar matematika yang dialami siswa SMP pada materi aljabar ditinjau dari mathematics anxiety (kecemasan matematika). Penelitian ini berjenis kualitatif dengan subjeknya yaitu 3 dari 32 siswa kelas VII SMP N 1 Pabelan tahun ajaran 2020/2021. Teknik pengambilan sampelnya menggunakan purposive sampling yaitu kategori siswa dengan kecemasan tinggi, sedang, dan rendah. Instrumen penelitian ini adalah peneliti itu sendiri, dengan instrumen tambahan yaitu tes materi aljabar dan pedoman wawancara. Indikator kesulitan belajar pada penelitian ini meliputi kesulitan dalam mentransfer pengetahuan, kesulitan dalam berhitung, kesulitan dalam persepsi visual, dan kurang memahami bahasa matematika. Berdasarkan hasil penelitian disimpulkan masing-masing siswa dengan tingkat kecemasan matematika yang berbeda yaitu tingkat kecemasan tinggi, sedang, dan rendah mempunyai kesulitan belajar yang berbeda pula. Siswa yang tingkat kecemasan matematikanya tinggi mengalami kesulitan tiap indikator kesulitan. Siswa yang tingkat kecemasan matematikanya sedang mengalami kesulitan untuk mentransfer pengetahuan, kesulitan dalam berhitung, dan kurang memahami bahasa matematis. Sedangkan siswa yang tingkat kecemasan matematikanya rendah hanya mengalami satu kesulitan belajar dalam materi aljabar yaitu kesulitan dalam mentransfer pengetahuan.
\end{abstract}

Kata kunci: Kesulitan Belajar Matematika, Kecemasan Matematika, Aljabar

Copyright (c) 2021 Arini Setyawati, Novisita Ratu

$\square$ Corresponding author: Arini Setyawati

Email Address: 202017010@ @student.uksw.edu (Jl. Diponegoro No 52-60, Salatiga, Kota Salatiga, Jawa Tengah) Received 28 July 2021, Accepted 23 August 2021, Published 08 Sepember 2021

\section{PENDAHULUAN}

Matematika adalah ilmu pengetahuan eksak yang membahas ide-ide dan konsep matematika di berbagai bidang (Fidayanti \& Shodiqin, 2020). Matematika sendiri memiliki peran yang penting dalam kehidupan masyarakat sehari-hari. Hal tersebut dilihat dari kegiatan yang dilakukan manusia hampir semua berhubungan dengan matematika, misalnya di bank, pusat perbelanjaan, kantor pos, dan lain sebagainya. Matematika juga merupakan disiplin ilmu yang berfungsi untuk mempelajari pola ikatan, pikiran, seni, dan bahasa yang dibahas secara nalar untuk membantu umat manusia mengetahui dan 
memahami masalah sosial, ekonomi, maupun alam (Fahrurrozi \& Hamdi, 2017). Oleh sebab itu, penting untuk mempelajari matematika.

Pentingnya mempelajari matematika sejalan dengan tujuan pembelajaran matematika yang diatur oleh Permendikbud No.21 Tahun 2016 tentang standar isi, diadakannya pembelajaran matematika di Sekolah Menengah Pertama yaitu agar siswa mampu: 1)menunjukkan sikap logis, kritis, analitis, cermat dan teliti, bertanggungjawab, responsif, dan tidak mudah menyerah dalam memecahkan masalah; 2)memiliki rasa ingin tahu, semnagat belajar yang kontinu, rasa percaya diri, dan ketertarikan pada matematika; 3)memiliki rasa percaya pada daya dan kegunaan matematika, yang terbentuk melalui pengalaman belajar; 4)memiliki sikap terbuka, objektif dalam interaksi kelompok maupun aktivitas sehari-hari; 5)memiliki kemampuan mengkomunikasikan gagasan matematika dengan jelas (Permendikbud, 2016).

Namun hal ini tidak sesuai dengan hasil belajar yang dicapai oleh siswa. Hasil dari pembelajaran matematika khususnya di Indonesia untuk jenjang Sekolah Menengah Pertama (SMP) masih belum optimal. Dilihat dari hasil UN di Indonesia tahun 2018 untuk mata pelajaran matematika rata-ratanya sebesar 43,34. Hasil UN tersebut relatif rendah dibandingkan mata pelajaran lain. Wilayah Provinsi Jawa Tengah khususnya di Kabupaten Semarang, hasil UN mata pelajaran matematika tahun 2018 pada jenjang SMP mencapai 45,63 dengan standar deviasi paling besar diantara mata pelajaran lain, yaitu 18,59 (PAMER UN PUSPENDIK, 2018).

Hasil wawancara dengan salah satu guru matematika di SMP Negeri 1 Pabelan, menyatakan masih terdapat permasalahan dalam pembelajaran matematika khususnya saat mempelajari materi aljabar, diantaranya siswa masih kesulitan untuk memahami soal matematika, kesulitan menerjemahakan soal cerita ke dalam model matematika dan kesulitan untuk mengoperasikan aljabar. Materi aljabar sendiri masih dianggap sulit oleh siswa. Ini dikarenakan representasi materi aljabar yang bersifat abstrak, mengandung simbol-simbol, dan variabel (Gella \& Bien, 2020). Seingga hal tersebut dapat diidentifikasikan sebagai suatu kesulitan yang dialami siswa terutama saat pembelajaran matematika.

Kesulitan belajar (learning disability) didefinisikan suatu kelainan yang menyebabkan seseorang yang mengalaminya menjadi kesulitan untuk melakukan aktivitas belajar secara baik (Jamaris, 2016: 3). Sedangkan menurut The United States of Education, kesulitan belajar merupakan gangguan terhadap satu atau lebih dari proses psikologis yang mencakup pemahaman dan penggunaan bahasa atau tulisan dimana terlihat dalam bentuk kesulitan yang meliputi kesulitan mendengar, berpikir, berbicara, membaca, menulis, mengeja, maupun berhitung (Darta, 2020). Kesulitan belajar matematika menurut Putri (2018) meliputi: 1) Kesulitan siswa terkait berbahasa dan memahami simbol; 2) Kesulitan mengartikan soal; 3) Kesulitan pada pemahaman konsep; 4) Kesulitan untuk menghitung. Menurut Rahmah (2019) kesulitan belajar matematika meliputi: 1)kesulitan dalam membedakan angka dan simbol; 2)tidak dapat mengingat dalil-dalil matematika; 3)menulis angka dalam ukuran yang kecil; 4)tidak mampu membaca, menulis, dan memahami simbol-simbol matematika; 5)memiliki kemampuan 
yang lemah dalam berpikir abstrak; 6)memiliki kemampuan metakognisi yang lemah. Sedangkan Jamaris (2016: 188) mengemukakan kesulitan belajar matematika siswa meliputi: 1) Lemah saat melakukan perhitungan matematika; 2) Kesulitan mentransfer pengetahuan pengetahuan; 3) Kurang memahami bahasa matematis; 4) Kesulitan terkait persepsi visual.

Kesulitan belajar seringkali didasari akibat datangnya rasa cemas yang dirasakan siswa saat pembelajaran matematika sehingga mengakibatkan pembelajaran matematika sulit untuk dipahami siswa (Utami \& Warmi, 2019). Sejalan dengan pendapat Husamah (2018) dan Idrus (2018) yang mengatakan salah satu faktor yang mempengaruhi kesulitan belajar yaitu faktor intrinsik(dari dalam diri sisiwa), yaitu dalam keadaan psikologis dan keadaan jasmani dan rohani siswa. Perasaan cemas yang dirasakan siswa saat pembelajaran matematika dapat disebut suatu kecemasan matematika (mathematics anxiety). Kecemasan sendiri merupakan gejala yang dialami seseorang berupa emosi yang membuat perasaan menjadi tidak nyaman, takut, khawatir, gelisah dan merasa tidak senang terhadap suatu hal yang mengancam dirinya yang disebabkan oleh lingkungan atau keadaan yang menekan sehingga dapat menghambat tujuan yang ingin dicapai (Satriyani, 2016). Ashcraft mengemukakan kecemasan matematika atau mathematics anxiety yaitu adalah sebuah perasaan tegang, cemas bahkan ketakutan yang dapat mengganggu dalam kinerja matematika (Ashcraft, 2002). Menurut Santri (2017), kecemasan matematika merupakan perasaan yang tidak nyaman yang muncul ketika sesorang menghadapi persoalan matematika atau berkaitan dengan ketakutan dan kekhawatiran saat menghadapi kondisi tertentu yang berhubungan dengan matematika. Sedangkan menurut Nurmila, kecemasan matematika adalah suatu perasaan takut, tegang maupun cemas yag dialami seseorang dalam menghadapi permasalahan matematika atau saat pelaksanaan pembelajaran matematika yang diikuti dengan munculnya berbagi gejala (Nurmila, 2016).

Chanavagh dan Sparow (H. E. Putri \& Muqodas, 2019) membagi kecemasan matematika ke dalam beberapa tingkatan yaitu kecemasan tinggi, sedang, dan rendah. Menurut penelitian yang telah dilakukan oleh Ikhsan (2019: 5), dikatakan siswa yang cenderung memiliki kecemasan tinggi, dinilai menghasilkan hasil belajar rendah dan sebaliknya. Hal tersebut menunjukkan pengaruh kecemasan terhadap hasil belajar.

Terdapat beberapa penelitian terdahulu, antara lain penelitian Nurlela dkk mengenai analisis kesulitan belajar matematika materi bentuk aljabar pada siswa SMP kelas VII, dimana dapat disimpulkan saat pembelajaran materi aljabar siswa melakukan kesalahan dalam mengerjakan soal, kekeliruan dalam perhitungan, dan kemampuan siswa untuk mengartikan soal masih kurang (Nurlela Nugraha et al., 2015). Penelitian lain dilakukan oleh Masykur dan Nasution mengenai analisis kesulitan belajar ditinjau dari kecemasan siswa pada pembelajaran matematika kelas X menyimpulkan kurangnya penguasaan konsep materi yang dipelajari sebelumnya menjadi satu dari faktor yang membuat siswa mengalami kesulitan belajar yang berkaitan dengan kecemasan saat mempelajari matematika (Masykur \& Nasution, 2017).

Bersamaan dengan uraian tersebut, maka dilakukan penelitian dimana tujuannya menganalisis 
bagaimana kesulitan belajar siswa SMP Negeri 1 Pabelan pada pembelajaran matematika materi aljabar yang ditinjau dari mathematics anxiety (kecemasan matematika) dengan masing-masing tingkat kecemasan tinggi, sedang, maupun rendah. Adapun aspek kesulitan belajar yang dianalisis pada penelitian ini yaitu menggunakan aspek kesulitan belajar menurut Jamaris. Selain itu, dalam penelitian ini peneliti memilih materi aljabar dikarenakan selain adanya permasalahan dalam mempelajari materi aljabar, materi aljabar sendiri dianggap sulit karena representasinya yang bersifat abstrak, mengandung simbol-simbol, dan variabel.

\section{METODE}

Penelitian ini berjenis deskriptif kualitatif. Penelitian kualitatif merupakan penelitian yang dimaksudkan untuk mengetahui berbagai kejadian yang dilalui subjek penelitian seperti persepsi, sikap dan tindakan, tekad, dan lain sebagainya secara keseluruhan melalui pendeskripsian kalimat atau bahasa dikondisi tertentu dengan menggunakan berbagai cara alamiah (Moleong, 2017). Penelitian deskriptif merupakan penelitian yang menyajikan gambaran mengenai suatu hal dengan cara mendeskripsikan. Penelitian deskriptif kualitatif ini tujuannya yaitu mendeskripsikan berbagai kesulitan belajar yang dialami siswa pada saat pembelajaran matematika materi aljabar yang ditinjau dari kecemasan matematika.

Tempat penelitian ini di SMP Negeri 1 Pabelan. Subjek penelitiannya yaitu 3 siswa dari 32 siswa kelas VII SMP N 1 Pabelan tahun ajaran 2020/2021. Teknik yang digunakan yaitu purposive sampling. Pemilihan subjek dilakukan dengan menyebarkan lembar angket kecemasan matematika kepada siswa. Berdasarkan hasil pengolahan angket, dipilih masing-masing satu dari kategori siswa dengan tingkat kecemasan tinggi, sedang, dan rendah. Pemilihan subjek juga berdasarkan pertimbangan guru.

Pada penelitian ini, instrumennya adalah peneliti itu sendiri, instrumen tes dan wawancara. Setelah subjek terpilih yaitu 1 siswa dengan tingkat kecemasan matematika tinggi, 1 siswa dengan tingkat kecemasan matematika sedang, dan 1 siswa dengan tingkat kecemasan matematika rendah, selanjutnya ketiga siswa tersebut mengerjakan soal tes matematika materi aljabar. Soal tes yang digunakan berupa 5 butir soal uraian materi aljabar yang sebelumnya telah divalidasi. Tes dilakukan untuk mengidentifikasi kesulitan-kesulitan apa saja yang dialami siswa saat mengerjakan soal matematika materi aljabar. Kemudian dilakukan wawancara lebih lanjut dengan subjek. Wawancara pada penelitian ini dilakukan setelah siswa selesai mengerjakan soal tes dengan tujuan mendapatkan informasi yang lebih mendalam mengenai kesullitan belajar yang dialami siswa. Metode wawancara yang digunakan adalah wawancara terstruktur. Selain itu, pada penelitian ini juga terdapat dokumentasi yaitu berupa gambar atau foto, rekaman atau video, dan catatan penting lain sebagai bukti dan pelengkap saat pengumpulan data. 


\section{HASIL DAN DISKUSI}

\section{Deskripsi Hasil Penelitian Kesulitan Belajar Matematika Siswa}

Setelah dipilih 3 orang siswa, kemudian siswa tersebut diberikan soal tes matematika materi aljabar. Soal tes terdiri dari 5 soal berbentuk uraian yang telah divalidasi oleh tiga orang ahli yaitu dua dosen matematika dan satu guru matematika. Hasil tes tersebut digunakan untuk menganalisis kesulitan belajar matematika yang dialami siswa. Berikut dideskripsikan kesulitan belajar siswa pada materi aljabar melalui hasil pekerjaan siswa dan wawancara:

\section{Siswa dengan Tingkat Kecemasan Matematika Tinggi}

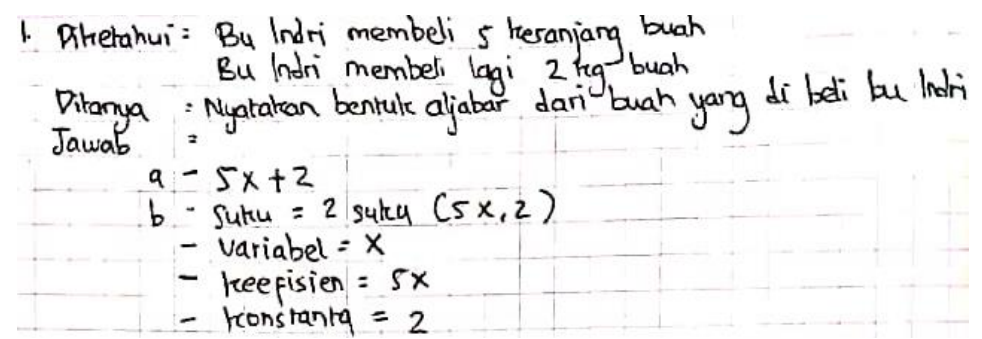

Gambar 1. Hasil Pekerjaan Siswa Tingkat Kecemasan Tinggi Soal No 1

Dari gambar diatas, terlihat siswa menuliskan informasi mengenai apa yang diketahui dan yang ditanyakan. Kemudian siswa juga dapat mengubah soal cerita menjadi bentuk aljabar dengan benar. Akan tetapi, siswa kurang tepat dalam menentukan koefisien. Berikut petikan wawancara dengan siswa: Peneliti : "Koefisiennya berapa nak?"

Siswa : " $5 x$ bu"

Peneliti: "Mengapa? Apakah kamu sudah yakin?"

Siswa : "Yakin bu. Karena koefisien itu yang ada x nya. Jadinya 5x"

Berdasarkan jawaban siswa dan hasil wawancara soal nomor 1, siswa mengalami kesulitan dalam mentransfer pengetahuan yaitu berupa kesulitan menentukan koefisien.

$$
\begin{aligned}
& \text { 2. }-6 u^{2}+7 u^{3}-(11-1-5) u v+4=5 a w a b a n \\
& -6 u^{2}+7 u^{3}-5 u v+4
\end{aligned}
$$

Gambar 2. Hasil Pekerjaan Siswa Tingkat Kecemasan Tinggi Soal No 2

Dari gambar diatas, terlihat siswa belum mengelompokan suku-suku yang sejenis dengan benar dan siswa hanya menjawab satu pertanyaan dari dua pertanyaan yang diberikan yaitu tidak menuliskan banyak suku dari bentuk sederhana tersebut. Terlihat juga siswa melakukan kesalahan hitung yaitu pada saat menjumlahkan suku-suku pada variabel uv. Berikut petikan wawancara dengan siswa:

Peneliti : "Berapa suku yang sejenis nak?"

Siswa : "Tidak tau bu"

Peneliti : "Suku yang sejenis - $(11-1-5) u v$. Coba jika dijumlahkan hasilnya berapa? 
Siswa : "-5uv"

Berdasarkan jawaban siswa dan hasil wawancara soal nomor 2, siswa mengalami kesulitan dalam mentransfer pengetahuan berupa kesulitan mengelompokan suku yang sejenis dan kelemahan dalam berhitung berupa kesulitan dalam menyedehanakan bentuk aljabar.

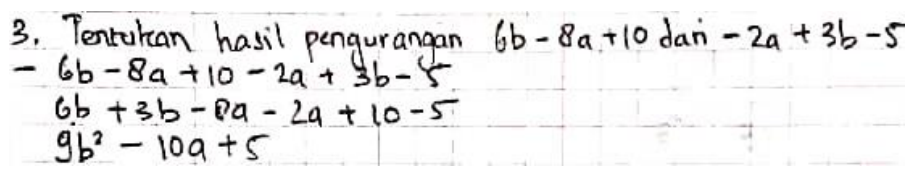

Gambar 3. Hasil Pekerjaan Siswa Tingkat Kecemasan Tinggi Soal No 3

Dari gambar diatas, terlihat siswa melakukan kesalahan dalam mengoperasikan aljabar. operasi yang ditanyakan dalam soal yaitu pengurangan, tetapi siswa mengerjakan dengan menggunakan penjumlahan operasi aljabar. Berikut adalah petikan wawancara dengan siswa:

Peneliti: "Coba nak dilihat lagi soalnya, itu kan ada kata-kata tentukan hasil pengurangan berarti harusnya menggunakan operasi pengurangan. Jadi yang betul bagaimana kira-kira?

Siswa : "Tidak tau bu"

Peneliti: "Kata hubungnya dari, maka-2a $+3 b-5$ dikurangi $6 b-8 a+10$. Hasilnya berapa nak?

Siswa : " $-10 a ”$

Peneliti: "Kalau $3 b$ dikurangi 6 b hasilnya berapa nak?

Siswa : "3b

Peneliti : "Apakah kamu masih merasa kesulitan pada saat mengoperasikan bentuk aljabar tersebut?"

Siswa : "Sejujurnya saya masih bingung kalau yang pengurangan atau tanda negatif bu"

Berdasarkan jawaban siswa dan hasil wawancara soal nomor 3, siswa lemah dalam berhitung berupa kesulitan dalam operasi pengurangan bentuk aljabar, melakukan kesalahan hitung, dan kurang teliti.

$$
\text { 4. ? }
$$

Gambar 4. Hasil Pekerjaan Siswa Tingkat Kecemasan Tinggi Soal No 4

Dari gambar diatas, siswa tidak bisa menyelesaikan soal nomor 4 terlihat dari jawaban siswa yang kosong atau tidak dikerjakan. Berikut adalah petikan wawancara dengan siswa:

Peneliti: "Mengapa soal nomor empat tidak dijawab nak? Apakah ada kesulitan?"

Siswa : "Saya nggak tahu dan bingung karena nggak ada angkanya dan gambarnya tidak penuh"

Berdasarkan jawaban siswa dan hasil wawancara soal nomor 4, siswa mengalami kesulitan dalam persepsi visual yaitu kesulitan menerapkan konsep aljabar dalam gambar bangun datar yang disediakan. 


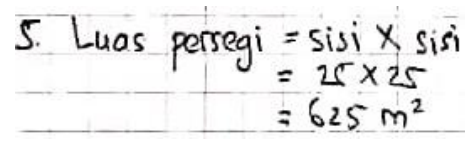

Gambar 5. Hasil Pekerjaan Siswa Tingkat Kecemasan Tinggi Soal No 5

Berdasarkan gambar diatas, siswa menggunakan rumus luas persegi untuk mencari luas kebun. Tetapi, terlihat bahwa siswa tidak memahami informasi yang tertulis pada soal seperti besar ukuran panjang dan lebar kebun sehingga jawabannya belum tepat. Berikut adalah petikan wawancara dengan siswa: Peneliti: "Coba diperhatikan lagi soalnya, apakah benar yang dicari adalah luas kebun jambu Pak Sapto? Coba dibaca pada kalimat terakhir"

Siswa : "Luas kebun tomat Pak Anton"

Peneliti: "Setelah itu bagaimana kalau yang dicari adalah luas kebun tomat Pak Anton?

Siswa : "Tidak tau bu"

Siswa : "Lalu berapa panjang kebun Pak Sapto dan lebar kebun Pak Sapto"

Siswa : "25 dan 15"

Berdasarkan jawaban siswa dan hasil wawancara soal nomor 5, siswa kurang memahami bahasa matematika terlihat dari ketidakmampuannya untuk mengubah soal cerita ke dalam bentuk matematika (tidak bisa menuliskan panjang dan lebar kebun dengan benar). Selain itu siswa juga kurang teliti dalam membaca soal sehingga dia kesulitan menentukan apa yang diketahui dan ditanyakan dalam soal.

\section{Siswa dengan Tingkat Kecemasan Matematika Sedang}

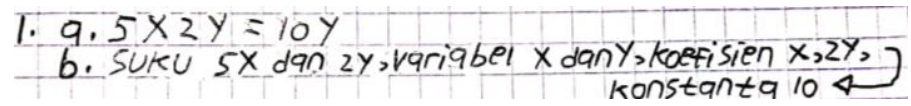

Gambar 6. Hasil Pekerjaan Siswa Tingkat Kecemasan Sedang Soal No 1

Dari gambar diatas, terlihat siswa sudah menjawab semua pertanyaan tetapi jawabannya masih belum tepat. Berikut adalah petikan wawancara dengan siswa:

Peneliti : "Mengapa 5 keranjang buah kamu tulis $5 x$ dan $2 \mathrm{~kg}$ kamu tulis $2 y$ ?"

Siswa : Yaa karena yang keranjang dimisalkan $x$ dan $\mathrm{kg}$ dimisalkan y"

Peneliti: "Satuan yang digunakan beda nak, yaitu dalam satuan kg dan satuan keranjang. Jadi kalau $2 \mathrm{~kg}$ sudah pasti beratnya dalam satuan $\mathrm{kg}$, tetapi kalau 5 keranjang kira-kira beratnya berapa kg ?" Siswa : "Tidak tau bu"

Peneliti : "Bisa dimisalkan simbol x atau huruf lain. Contoh $5 x+2$. Koefisien dan konstantanya berapa? Siswa : "Koefisien 2 dan konstanta $5 x "$

Berdasarkan jawaban siswa dan hasil wawancara soal nomor 1, siswa kurang memahami bahasa matematika dimana siswa tidak dapat mengubah soal cerita ke dalam bentuk ajlabar dan siswa mengalami kesulitan dalam mentransfer pengetahuan berupa kesulitan menentukan menentukan koefisien dan konstanta. 


\section{2. $-6 v^{2}-17 u v+4+7 v^{3}$}

Gambar 7. Hasil Pekerjaan Siswa Tingkat Kecemasan Sedang Soal No 2

Dari gambar diatas, terlihat siswa sudah menjawab soal benar tetapi tidak disertai dengan cara penyelesaiannya. Berikut adalah petikan wawancara dengan siswa:

Peneliti: "Bagaimana cara kamu menyelesaikan soal nomor 2 ini?

Siswa : "Dikelompokkan \& dihitung. $-6 u^{2}-11 u v-u v-5 u v+4+7 u^{3}=-6 u^{2}-17 u v+4+$ $7 u^{3}$,

Peneliti: "Betul jawabannya sudah benar nak, tetapi sebaiknya penulisan suku pada bentuk aljabar diurutkan sesuai urutan alfabet dan suku yang pertama mempunyai pangkat varibel tertinggi. Sehingga jawabannya yang lebih tepat adalah $7 u^{3}-6 u^{2}-17 u v+4 "$

Berdasarkan jawaban siswa dan hasil wawancara soal nomor 2, siswa tidak mengalami kesulitan dalam menyelesaikan soal, tetapi jawaban siswa masih kurang lengkap tidak menuliskan banyak suku.

\section{3. $9 b-109+5$}

Gambar 8. Hasil Pekerjaan Siswa Tingkat Kecemasan Sedang Soal No 3

Dari gambar diatas, terlihat siswa menjawab soal nomor 3 tetapi tidak menyertakan langkah pengerjaannya dan jawaban tersebut masih belum tepat. Berikut petikan wawancara dengan siswa:

Peneliti: "Bagaimana cara kamu menyelesaikan soal nomor 3 ini nak?"

Siswa : "Dikelompokkan bu, lalu dihitung. $6 b+3 b-8 a-2 a+10-5=9 b-10 a+5$ "

Peneliti : "Coba soal diperhatikan lagi. Apakah benar operasi yang seharusnya digunakan penjumlahan?

Siswa : "Pengurangan.

$$
6 b-3 b-8 a-(-2 a)+10-(-5)=3 b-8 a+2 a+10+15=3 b-6 a+15 ”
$$

Peneliti: "Oke nak, coba dilihat lagi soalnya. Itu ada kata "dari" maka cara pengerjaannya bagaimana?"

Siswa : “ $-2 a+3 b-5$ dikurangi $6 b-8 a+10$ bu. Jadi...

$$
-2 a-(-8 a)+3 b-6 b+-5-10=-2 a+8 a+-3 b+-15=6 a+-3 b+-15 \text { ” }
$$

Berdasarkan jawaban siswa dan hasil wawancara soal nomor 3, siswa mengalami kesulitan yaitu kelemahan dalam berhitung berupa kesalahan hitung karena kurang teliti.

\section{4. keliling $=4 x$}

Gambar 9. Hasil Pekerjaan Siswa Tingkat Kecemasan Sedang Soal No 4 
Dari gambar diatas, terlihat siswa sudah menjawab soal nomor 4 dengan jawaban yang benar, tetapi tidak menyertakan langkah pengerjaannya. Berikut adalah petikan wawancara dengan siswa:

Peneliti : "Pada soal nomor 4, disuruh menghitung apa nak?

Siswa : "Keliling bu"

Peneliti : "Lalu bagaimana cara kamu menyelesaikan soal nomor 4 ini? Coba dijelaskan"

Siswa : "Kalau keliling kan sama aja menghitung semua garis-garis yang dipinggir dan sisinya kan x. Kalau garis yang y ditarik ke pojok bawah kan jadi persegi bu. Berarti sama aja $x+x+$ $x+x=4 x "$

Berdasarkan jawaban siswa dan hasil wawancara soal nomor 4, siswa tidak mengalami kesulitan dalam menyelesaikan soal nomor 4 .

$$
5.15 \times 25=375 \mathrm{~m}^{2}
$$

Gambar 10. Hasil Pekerjaan Siswa Tingkat Kecemasan Sedang Soal No 5

Dari gambar diatas, terlihat siswa sudah menjawab soal nomor 5 tetapi jawaban masih belum tepat dan jawaban tidak disertai cara pengerjaannya. Berikut adalah petikan wawancara dengan siswa: Peneliti : "Apakah kamu mengalami kesulitan? Bagaimana cara kamu menyelesaikannya?" Siswa : "Bingung, tapi kalau saya no 5 yang dicari luas jadi $p \times l=15 \times 25=375 \mathrm{~m}^{2}$ ", Peneliti: "Lalu, berapa ukuran panjang dan lebar kebun jambu Pak Sapto?" Siswa : "25m lebih panjang dan 15m kurang dari panjang sisi kebun jambu Pak Anton” Peneliti : "Bagaimana maksut dari kalimat tersebut nak?"

Siswa : "Tidak tau bu"

Berdasarkan jawaban siswa dan hasil wawancara soal nomor 5, siswa kurang memahami bahasa matematika terlihat dari ketidakmampuan siswa untuk mengubah soal cerita tersebut ke dalam bentuk matematika (tidak bisa menuliskan panjang dan lebar kebun dengan benar).

\section{Siswa dengan Tingkat Kecemasan Matematika Rendah}

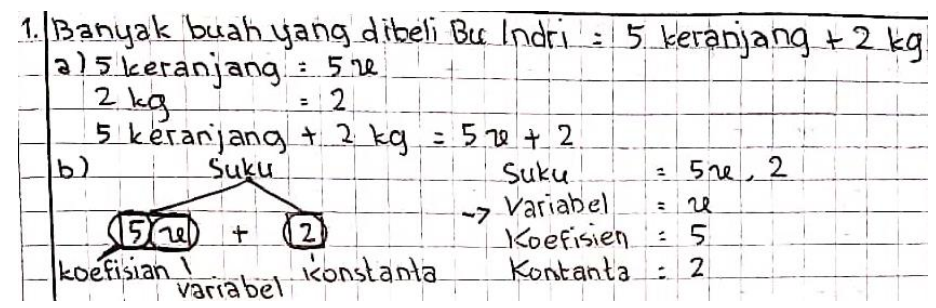

Gambar 11. Hasil Pekerjaan Siswa Tingkat Kecemasan Rendah Soal No 1

Dari gambar diatas, terlihat siswa mengerjakan soal nomor 1 dengan runtut dan benar. Siswa juga memisalkan keranjang dalam variabel $\mathrm{x}$ dan menuliskan bentuk aljabarnya. Selain itu siswa juga mampu menentukan unsur aljabar dengan tepat. Berikut adalah petikan wawancara dengan siswa: 
Peneliti: "Adakah kesulitan yang kamu alami? Bagaimana cara kamu menyelesaikannya nak?

Siswa : "Tidak bu. Kan banyak keranjang belum diketahui, dimisalkan x. Jadi bentuk aljabar $5 x+2 . "$

Peneliti : "Oke betul.... Lalu pertanyaan yang b jawabannya apa nak?"

Siswa : "Suku Ada 2 bu, $5 x$ dan 2. Variabel x. Koefisien dan konstanta 5 dan 2"

Berdasarkan jawaban siswa dan hasil wawancara soal nomor 1, siswa tidak mengalami kesulitan maupun kesalahan dalam menyelesaikan soal nomor 1.

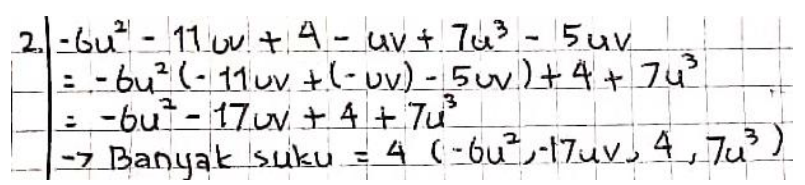

Gambar 12. Hasil Pekerjaan Siswa Tingkat Kecemasan Rendah Soal No 2

Dari gambar diatas, terlihat siswa sudah menjawab soal dengan benar disertai langkah pengerjaannya dan mampu menuliskan banyak suku. Berikut adalah petikan wawancara dengan siswa: Peneliti: "Apakah kamu mengalami kesulitan di soal ini? bagaimana cara kamu menyelesaikannya?" Siswa : "Tidak kesulitan bu. Yang sejenis dikelompokkan dulu bu $-11 u v+(-u v)-5 u v$. Setelah itu dihitung jawabannya $-6 u^{2}-17 u v+4+7 u^{3} "$.

Peneliti : "Betul jawabannya sudah benar nak, tetapi sebaiknya penulisan suku pada bentuk aljabar diurutkan sesuai urutan alfabet dan suku yang pertama mempunyai pangkat varibel tertinggi. Sehingga jawabannya yang lebih tepat adalah $7 u^{3}-6 u^{2}-17 u v+4$ "

Berdasarkan jawaban siswa dan hasil wawancara soal nomor 2, siswa tidak mengalami kesulitan maupun kesalahan dalam menyelesaikan soal nomor 2.

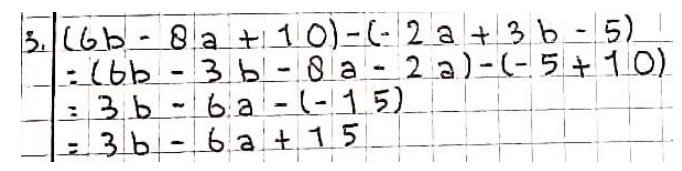

Gambar 13. Hasil Pekerjaan Siswa Tingkat Kecemasan Rendah Soal No 3

Dari gambar diatas, terlihat siswa sudah mengerjakan soal disertai langkah pengerjaannya, tetapi jawaban masih belum tepat. Berikut adalah petikan wawancara dengan siswa:

Peneliti: "Bagaimana cara kamu menyelesaikan soal nomor 3 ini nak?"

Siswa : " $(6 b-8 a+10)-(-2 a+3 b-5)=(6 b-3 b-8 a-2 a)-5+10=3 b-6 a-$

$$
(-15)=3 b-6 a+15 ”
$$

Peneliti: "Oke, apakah benar sudah yakin caranya seperti itu nak?

Siswa : "Yakin bu"

Peneliti: "Sekarang coba dibaca lagi soalnya nak. Disitu ada kata "dari” berarti harusnya 


\section{bagaimana?}

Siswa : "Saya tidak tau bu"

Berdasarkan jawaban siswa dan hasil wawancara soal nomor 3, siswa mengalami kesulian dalam menerapkan pengetahuan yang dimiliki berupa kesulitan menerapkan operasi pengurangan jika terdapat kata "dari".

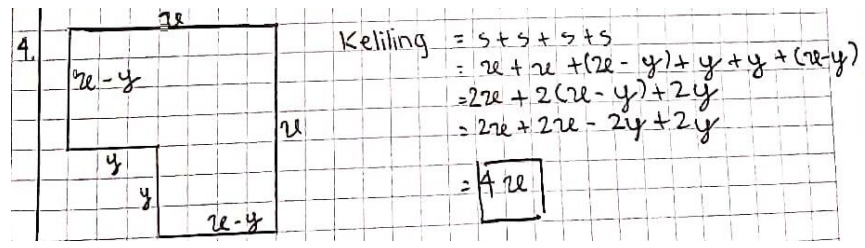

Gambar 14. Hasil Pekerjaan Siswa Tingkat Kecemasan Rendah Soal No 4

Dari gambar diatas, terlihat siswa menyelesaikan soal nomor 4 disertai langkah pengerjaan yang runtut dan benar. Berikut adalah petikan wawancara dengan siswa:

Peneliti : "Bagaimana cara kamu bisa mendapatkan $x-y$ ?

Siswa : "Kan ini $\mathrm{x}$, tapi kepotong $\mathrm{y}$. Jadinya $x-y$. Karena dicari keliling maka dijumlah hasilnya $4 \mathrm{x}$ " Berdasarkan jawaban siswa dan hasil wawancara soal nomor 4, siswa tidak mengalami kesulitan maupun kesalahan dalam menyelesaikan soal nomor 4.
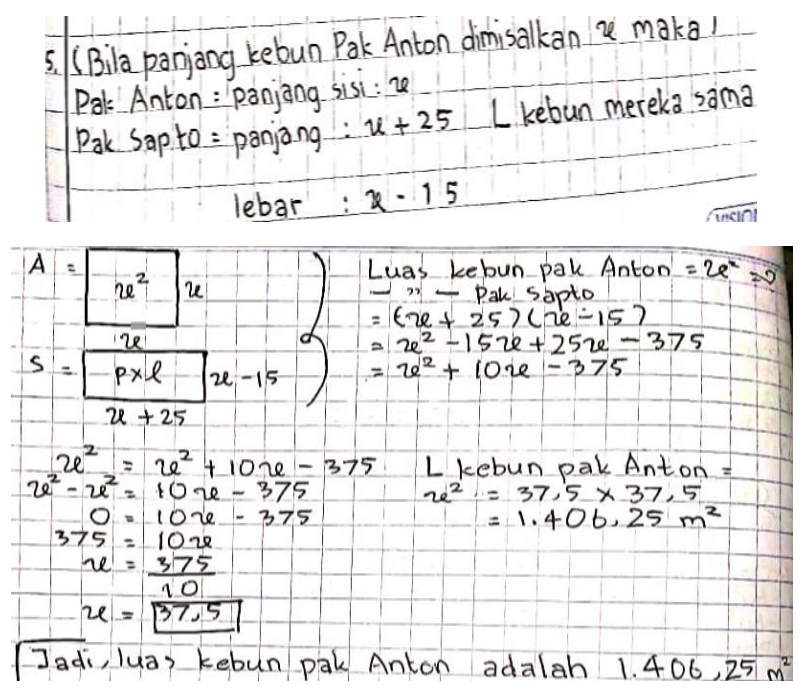

Gambar 15 dan 16. Hasil Pekerjaan Siswa Tingkat Kecemasan Rendah Soal No 5

Dari gambar diatas, terlihat siswa mengerjakan soal dengan jawaban yang runtut dan benar. Siswa juga mampu memisalkan ukuran panjang dan lebar kebun Pak Sapto dengan bentuk aljabar. Berikut adalah petikan wawancara dengan siswa:

Peneliti: "Mengapa panjang kebun pak sapto ditulis $x+25$ dan lebarnya $x-15$ ?"

Siswa : "Karena dalam soal ukuran panjang kebun pak sapto $25 \mathrm{~m}$ lebih panjang dari sisi kebun pak 
anton dan lebar kebun pak sapto 15 m kurang dari panjang kebun pak anton maka ditulis gitu”

Peneliti : "Oke, lalu setelah itu bagaimana?"

Siswa : "Karena luas kebun pak anton dan pak sapto sama jadinya $x^{2}=(x+25)(x-15)$ terus dihitung hasilnya 37,5. Terus dihitung luasnya.

Berdasarkan jawaban siswa dan hasil wawancara soal nomor 5, siswa tidak mengalami kesulitan maupun kesalahan dalam menyelesaikan soal nomor 5 .

\section{KESIMPULAN}

Hasil dari analisis data didapat kesimpulan bahwa masing-masing siswa dengan tingkat kecemasan yang berbeda memiliki kesulitan belajar matematika yang berbeda pula satu sama lain. Adapun kesulitan yang dialami sisswa dapat disimpulkan sebagai berikut 1) Siswa dengan tingkat kecemasan matematika tinggi mengalami kesulitan dalam mentransfer pengetahuan (berupa kesulitan menentukan koefisien dan kesulitan mengelompokan suku yang sejenis), kelemahan dalam berhitung (berupa kesulitan dalam menyedehanakan bentuk aljabar, kesulitan dalam operasi pengurangan bentuk aljabar, melakukan kesalahan hitung, dan kurang teliti), kesulitan dalam persepsi visual (berupa kesulitan untuk menerapkan konsep aljabar dalam gambar bangun datar yang disediakan), dan kurang memahami bahasa matematika (dilihat dari ketidakmampuannya untuk mengonversikan soal cerita tersebut ke dalam bentuk aljabar). Sedangkan siswa dengan tingkat kecemasan matematika sedang memiliki kesulitan seperti mentransfer pengetahuan (berupa kesulitan menentukan koefisien dan konstanta), kurang memahami bahasa matematika (dilihat dari ketidakmampuannya untuk mengonversikan soal cerita tersebut ke dalam bentuk aljabar), dan kelemahan dalam berhitung (berupa kesalahan hitung karena kurang teliti). Terakhir, siswa dengan tingkat kecemasan matematika rendah mengalami kesulitan dalam mentransfer pengetahuan (berupa kesulitan menerapkan operasi pengurangan aljabar jika terdapat kata "dari”).

\section{REFERENSI}

Ashcraft, M. H. (2002). Math anxiety consequences. Current Directions in Psychological Science, 181185. http://www.mccc.edu/ jenningh/Courses/documents/math_anxiety.pdf

Darta, I. N. (2020). Upaya Memberikan Bantuan Terhadap Siswa Yang Mengalami Kesulitan Belajar Melalui Pembentukan Klinik Mata Pelajaran. Nilacakra.

Fahrurrozi, \& Hamdi, S. (2017). Metode Pembelajaran Matematika (D. S. M. Ibrahim (ed.)). Universitas Hamzanwadi Press.

Fidayanti, M., \& Shodiqin, A. (2020). Analisis Kesulitan Dalam Pembelajaran Matematika Materi Pecahan. 3(1), 88-96.

Gella, N. J. M., \& Bien, Y. I. (2020). Aljabar Linear Dasar Berbasis IT (Scilab, Geogebra Dan Microsoft Mathematics). Deepublish. 
Husamah, Pantiwati, Y., Restian, A., \& Sumarsono, P. (2018). Belajar dan Pembelajaran. UMM Pers Malang.

Idrus, E. (2018). Membongkar Psikologi Belajar Aplikatif. Guepedia.

Ikhsan, M. (2019). Pengaruh Kecemasan Matematis Terhadap Hasil Belajar Matematika. De Fermat : Jurnal Pendidikan Matematika, 2(1), 1-6. https://doi.org/10.36277/defermat.v2i1.28

Jamaris, M. (2016). Kesulitan Belajar Perspektif, Asesmen, dan Penanggulangannya. Ghalia Indonesia.

Masykur, R., \& Nasution, S. P. (2017). Analisis Kesulitan Belajar Ditinjau Dari Kecemasan Peserta Didik Pada Pembelajaran Matematika Kelas X Di SMA Muhammadiyah 1 Kota Agung Kab.Tanggamus Tahun Pelajaran 2016/2017. 1(1), 1-3.

Moleong, L. J. (2017). Metodologi Penelitian Kualitatif. PT Remaja Rosdakarya.

Nurlela Nugraha, Gida Kadarisma, \& Wahyu Setiawan. (2015). Analisis kesulitan belajar matematika materi bentuk aljabar pada siswa smp kelas vii. 01(02), 323-334.

Nurmila. (2016). Hubungan Antara Kecemasan Matematika Dan Kesulitan Belajar Dengan Perilaku Belajar Siswa Di SMPN 3 Tanete Riaja Kabupaten Barru.

Permendikbud. (2016). Permendikbud Nomor 21 Tahun 2016 tentang Standar Isi Pendidikan Dasar dan Menengah.

PUSPENDIK. (2018). PAMER UN. https://hasilun.puspendik.kemdikbud.go.id

Putri, H. E., \& Muqodas, I. (2019). Pendekatan Concrete-Pictorial-Abstract (CPA), Kecemasan Matematis, Self-Efficacy Matematis, Instrumen, dan Rancangan Pembelajarannya. UPI Sumedang Press.

Putri, Y. E. (2018). Analisis Kesulitan Belajar Siswa Ditinjau Dari Kemampuan Berpikir Logis Pada Materi Pokok Segitiga.

Rahmah, D. A. (2019). Kesulitan Belajar Siswa Pada Proses Pembelajaran Matematika. 945-949.

Santri, F. S. (2017). Ada Apa Dengan Kecemasan Matematika? Journal of Medives , 1(1), 59-65. http://e-journal.ikip-veteran.ac.id/index.php/matematika

Satriyani. (2016). Pengaruh Kecemasan Matematika ( Mathematics Anxiety) Dan Gender Terhadap Kemampuan Pemecahan Permasalahan Matematika. 156.

Utami, A. H., \& Warmi, A. (2019). Analisis kesulitan belajar ditinjau dari rasa kecemasan matematika. 617-622. 